\title{
Protect your self (building self-awareness in preventing lesbian, gay, bisexsual, and transgender among elementary school students through counseling)
}

\author{
Amirah Diniaty ${ }^{1}$, Suhertina $^{2}$ \\ ${ }^{12}$ State Islamic University Sultan Syarif Kasim Riau
}

\section{Article Info \\ Article history: \\ Received Oct $25^{\text {th }}, 2018$ \\ Revised Oct $10^{\text {th }}, 2018$ \\ Accepted Nov ${ }^{\text {rd }}, 2018$}

\section{Keyword:}

LGBT,

Elementary School Students,

Awareness,

Counseling.

\begin{abstract}
This research aims to highlight how to prevent LGBT cases that initially occur to primary school student since they are susceptible to be the victims of pedophilia. During this age, they still think concrete, so that they must get proper and correct understanding to protect themselves from LGBT cases. This was an action research by providing counseling services to children: group counseling and information services. The main issue was how to built the students' awareness in protecting themselves when they interact to the foreigners. This research involved 15 five grade students of Islamic primary school in Pekanbaru and 30 fourth and third grade students of Public Elementry School in Bangkinang. The findings suggest that most students were interested in joining couceling sessions especially in discussing personal issues. The challenge is counselor needs to provide natural, clear, and understandable information packed with concrete examples and interesting media.
\end{abstract}

(C) 2018 The Authors. Published by Redwhitepress.

This is an open access article under the CC BY-NC-SA license (https://creativecommons.org/licenses/by-nc-sa/4.0/

\section{Corresponding Author:}

\section{Amirah Diniaty}

State Islamic University Sultan Syarif Kasim Riau

Email: amirah.diniaty@gmail.com

\section{Introduction}

Primary school children (from 6 to 10 years old) are having their growing age. They are full of hope, innocent, funny and think concrete and real about life. But since their growing age begin, it is suspectible for them to be a criminal victim in their environment such as sexual harassment from people who commit pedophilia. Ronken and Johnson (2012) described annual statistic data from police dept in Queensland in the year 2007-2008. 82\% sexual herryment victim were children under 18 years old (female) and $18 \%$ (male), then $56 \%$ under 16 years old and $46 \%$ under $0-14$ years old.

In Indonesia the sexual harrashment rate reaches $58 \%$ from 21.736 .859 ,criminal report against children in the year 2010-2014. The Indonesian Child Protection Commission received 3.737 report about violation against children in the same period, and $58 \%$ was sexual abuse against children (Sirait, 2015). Example case in Lampung in Nov 2017 where 42 students under 12-17 years old were desecrated by a teacher but then it was found out that the teacher was a gay. But the tragic thing was 11 students from the victims were addicted and active in doing oral sex - ever since (news/ /Wednesday 08 November).

Brooman fulls explained based on his research (In Ronken and Johnson, 2012) that 73\% children did not let their parents know about the sexual harrashment they got. Some even never spoke about this, because they felt depressed, dishonor, or afraid that their parents would put the blame on them, having psychic trauma, or did not know where to make report. Most of the parents just found out too late, where they saw that their children's behavior changed, for example afraid of going outside or meet new people and felt pain when their children wanted to pass water or defecated. Child welfare information gateway (Margaretha 2014) described 
about effort that pedophiles did to make victims stayed silent and told no one about his action. The effort was by providing them attention, finding out children's hobbies of favorite things such as giving them presents, made children stayed away from their community and environment, acted as if he found out the reason to be with them, visited nice places or places kids to go, using children's curiosity by sex humor stories, pornography, and sexual game.

The pedophiles could be from close friends of the family, relatives or even the parents themselves. According to Dewi Kurniawan (2017) needed to be differentiate, pedophilia and sexual abuse. The difference was the intensity. Pedophilia is a psychiatric disorder it possesses which someone, 16 years old or more or at least five years older from his victim, and he has social dysfunction, trouble in job or other disturbances. It will occur this pedophilia many times at least six months.

While sexual abuse toward children adult does which to children happens because of one condition such as stress, there is no adult couple and this action takes place accidentally, no repetation. This action begins when the person tries to get trust and friendship with the child. He tries to attack child's curiosity and see child's ability in taking care of himself by giving some jokes about sex play hobby horse, touching child's back, kissing, and playing something that lead to sex (Dwi Kurniawan 2017,in Margaretha 2014).

Dwi Kurniawan (2017) explained that most of normal children usually do not feel annoyed and will show their curiosity. They will go further by doing sex action directly such as show off his genital, touch child's genital, masturbation then intercourse. The child will not understand what is really going on. They do not get the idea what he does is sexual activity, even he does not know that the doer did before is wrong because he has limited knowledge about sex.

Hertinjung (2014) in his research found out the effect that happened to pedophilia victims had made child lose his personal space limits ,trust and his identity. This would bring psychological impact to the victim, which would make child fear because he has to do something which he has never seen, or heard before. It also could make him lose his self confidence and fear excessive.

Other impact can make the victim into the actor, because his old background before. This sexual abuse could lead them to be lesbian, gay, bisexual or transgender which is called LGBT.

The anxiety about LGBT started in 2015, when Indonesia reached the fifth place for LGBT in the world after China, India, Europe and America (CIA survey in topikmalaysia.com). There is about 3\% LGBT people in Indonesia, and based on the data, it was found out that there are 3 LGBT citizen among 100 citizen. Infact this homosexual behavior had high risk to make people infected with deadly desease HIV/Aids and anal cancer. The data showed that gay and bisexual had high risk to get HIV/Aids (National Geographic.co.id/25/2/2016). According to public health policy analyst, the homo sexual people has increased sharphy to get HIV/Aids (225\%) in 2016 .

The anxiety about increasing LGBT numbers and children as victim, is getting worse since it is very easy for children to get internet access and more online information about LGBT. This information made in the form of printed or online media by LGBT supporters as propaganda. And the children are very sensitive in this matter, because of their curiosity, their passion for adventure, challenge, and their tendency to pay responsibility for their action without well consideration (Datun.www.depkes.go.id/accessed June, 29,2015).

The school counselor must built the students' awareness in protecting themselves when they interact to the foreigners. Gybers and Henderson (in cladding, 2012:463) convinced that primary school counselor is in the front line to defend the mental health movement in environment. Then Border and Druri (in gladding,2012: 460) explained that based on research which had been done for more than 30 years it was found that counseling intervension in school environment big impact for students personal development and their educational development.

Partin in the 1993 found out in his research that counselor in primary school spent more time with pupils in group activity ( Gladding, 2012:464). The implementation of group conseling service for children is a preventive way to prevent and to make a good situation for child self concept (Gladding, 2012). The most important thing is to have an understanding about themselves including their personal development task that they have to go through, by information service which was adjusted to pupil development behavior.

The question that has to be answered is; how the application of group counseling activity and information service for primary school student can guide them to protect themselves from LGBT behavior? This article discuss about the answer for that question. 


\section{Method}

This research is an action research which is done to find out, analyze, interperate, and do counseling, activity. This action research is a kind of group counseling and information service for primary school student, basically follow the pattern which is suggested by Kemmis and MC taggart, with steps :planning, action, observation and reflection (Suwarsih Madya, 1994)

This pra step action contains survey activity by interviewing the counseling teacher in Islam Integrated Primary school in Pekanbaru and the other one is primary school in Bangkinang city Riau province. This research is about child self awareness to prevent LGBT. So far there has no counseling service activity for students yet, and it becomes the reason why this activity need to be done.

Next, planning about group counseling service is and information service by choosing member, time, place of activity and materials which are need it. There are fifteen student from the fifth grade who are chosen by accident from Islamic Integrated Primary School in Pekanbaru. All of the students was girls. These students are from group counseling service in Friday program. 30 fourth and third grade students of Public Elementry School in Bangkinang were chosen by the teacher after morning excercise activity; 12 girls and 18 boys. They are gathered in one room. Data analysis by qualitatively.

\section{Results and Discussion}

\section{Action}

\section{Group counseling guidance service}

Researcher did the group counseling to respondents about one and a half hours. The researcher was as group leader implemented all 4 steps, diversion, activity, and ending (Prayitno 2017). Group counseling started by greeting, said a pray, explained about the purpose, the benefit, and how to apply the activity, then it was continued with an introduction.

In the opening student were enthusiastic, they were active and full of energy in introducing themselves to the group leader. There was a dynamic process here where the group member felt so energetic, happy. It could see it from the example of expression Df when she introduced herself: "My name is Df. I am the oldest from three brothers. I like reading al Quran".

The next activity is diversion step, someone asked group members to be active and showed their willingness in discussing the topic a leader would give which. There is no difficulty in this step, all members understood and they continued the activity.

In this activity step the leader explained with simple words that there were two kinds of human created by Allah SWT man and woman. They discussed it the difference and identification between man and woman in many aspects. Started from physical, role and duty. Process in this step was dynamic.

The topic developed and discussed about what part of body form woman which was called and included aurat in Islam, it can not be seen, or touched for the person who was not muhrim (not significant person). The group member (LS) said, "except face and palm for a woman and accept belly bottom and knee for man". Other group member (DF) explained that it was an obligation for the girl to cover her aurat .

The leader guided the topic about which part of the body it allowed that to be touched by others such a teacher, friend or other adult? The group members told their experience. TF told that her father's friend touched her shoulder once. DW said: "My brother's friend held my hand and it embarrassed me. And there were group members who were just also silent there. After that, the group leader played video song titled "I take care of my self "by Sri Seskya Situmorang (www.YouTube.com/watch). The group members watched and sang the song together. The contain of the song : it can touch good touch was at shoulder to finger tip and from knee to toe tip. Body covered by underwear and lip, can not touch or call bad touch. Mother and doctor only could touched. Confusing touch was a kind of touch from shoulder to knee. This part is also only for students themselves, mother and doctor. It thought children to be brave to say no if someone bad touch stayed away, or reported to their parents soon.

The group members was discussed from their experience and what must they do to protect them self, from that song. Their self awareness more higher than before. TF (group member) said that she would scream if someone disturbed her. Other members also expressed their feeling and thought about planning to stay away from bad person toward them.

The next step in group counseling was ending process. The group members said that they were happy with this activity and gained knowledge about how to protect themselves from bad action. 


\section{Information service}

The topic about how to protect themselves was an interesting topic for they third and fourth grade primary school in information service. It was begun with question; what the difference between man and woman? They answered enthusiastically by raising their hands. Almost 75\% students raised their hand and explained about the question. Generally they could see the difference, about physic.

After that step, discusing process about how many disturbances made by other people toward part of the body(man) and (woman), and how they could protect themselve. Students were more enthusiastic to follow this activity which was also included games and some presents in it. In fact students were able to describe their opinions, answered questions, gave solution to the questions which were given to them smoothly and logically

The fact in this process is they were willing to to tell about their personal experience. They told such as when girl's leg was touched by a boy at school hours in canteen and that incident made her angry. Other students was brave to tell their experience, after that story. They got the same treatment from adults such as their brothers friend or uncles friend.

Next process is the discussion about reaction toward the touch, and how to protect their self from foreigners. Two student practice that situation in front of the class. Students become more enthusiastic and played role how to scream and asked for help. They understood how important to told teacher or parents about bad experience or incident especially when it put their lives in danger.

\section{Reflection}

The reflection result got by discussion with the observer who was school counselor. She observered the activity in group counseling and information service increased the students self awareness. Student could protect themselves and prevent from the sexual harrashment. According to the observer one hour was very limited time to discuss this topic widely. Generally the oberver's said the program was success.

\section{Cycle}

The second cycle, the interview was held in one of the group members a week after the activity. The result showed that participant was very careful if she faced stranger especially when the strangers touch her part body though the person was her brothers friend. From this second cycle it could be concluded that activity which was done in cycle one had brought positive impact. Most of students hoped to do the same activity for other time.They felt happy and enthusiastic as school counselor said, "children were happy and asked when would the same activity be held again".

Their experience in the information service and group counseling by using the song and sosio drama was interesting and could be referenced as topic how to protect themselves to prevent from LGBT. It also shown their true identity (as boy or girl) and make them accustomed to behaving based on their real/ true identity and made them stay away from sexual abuse such as forbidden touch.

Charles W Socarides (in Melany Budiarins Santoso 2016) explained that LGBT appeared in someone not because of the genetical factor. The changes in someone which turned him/her into gay or lesbi was her/his insight, the conscious mind and life experience. The psycho social factor was more dominant. People who got genetic disorder did not change their orientation to like their own kind just like LGBT. LGBT could handled by therapy to change his way of thinking. But the real problem was, many LGBT people thought there was nothing wrong with them and nothing to worry about. They did not think they had the mental disease. They even made LGBT as a life style in the society.

In Neurosains analysis, it found that people would just know they felt something was correct if the limbic system worked, and it was close to a positive response which they got in the environment. Students ignorance would make them in high risk to contract and turned to be LGBT. It was possible because both of the parents and leader did not have a good response toward children's behavior so they would record it into their behavior, then it would be into their sub consciousness outside (cortex cerebri)cerebrum.

According to Sell (1996) the cortex cerebri had a function to accept and processed the information that enter the brain then motor motivity would react with body movement, and kept it in the memory barn in cortex, and would appear anytime the human need it. Coleman (1997) explained that this ability would form instinct and unexpected reaction from human when they faced thing they faced before. It meant, children became LGBT because of their mistake behavior before in the past and no one ever tried to help and fixed them. This problem became important attention for a group leader, who was counseling teacher in doing his/her group guidance counseling for elementary school children.

Then in the implementation group counseling to child according to Kathryn Geldard and DavGeldard (2012:117) the counselor had to pay attention to the child who couldn't control himself and couldn't control 
his happiness. The children could act, or destroy property. That the observer did not find such a case like this in the activity. It probably caused it they come from Islamic integrated elementary school, so they had strong religious value. The religion values was made the good understanding, so they do not grow up as aggressive generation and prevent them from LGBT.

\section{Conclusions}

School counselor must do their duty as an educator, guide and the best friend for the primary student, to built their self awareness in protecting themselves when they interact to the foreigners. The hard challenge for a counselor in doing counseling service for elementary school students was the needs of clear information and natural communication which made easy for students to understand. For that challenge, school counselor must improve their knowledge and skill counseling. They could use games and interesting media such as video and music in counseling children.

However, school counselor must care and be careful from the propaganda LGBT program made which through printed and online media. Primary students could get it every way and easy. It has made people worried that the sexual abuse number would increase. School counselor must have good networking with parents and community to protect the student from LGBT.

\section{References}

Dwi Kurniawan \& Farida Hidayati. (2017). Penyalahgunaan Seksual dengan Korban Anak-Anak (Studi Kualitatif Fenomenologi Terhadap Pelaku Penyalahgunaan Seksual dengan Korban Anak-Anak). Jurnal Empati, Januari 2017, Volume 6(1), 120-127

Hertinjung, W. S. (2014). The dynamic of causes of child sexual abuse based on availability of personal space and privacy. Fakultas Psikologi Universitas Muhammadiyah Surakarta.

Idham Kholid - detikNews. (2017). Cabuli 42 Murid, Guru Olahraga di Lampung Ditangkap. https://news.detik.com/berita/d-3717994/Rabu 08 November 2017, 10:33 WIB

Info Datin, Situasi Kesehatan Reproduksi Remaja. www.depkes.go.id/ diakses Jun 29, 2015.

Kathryn Geldard \& David Geldard. (2012). Konseling Anak-Anak Sebuah Pengantar Praktis. Jakarta. PT Indeks.

Laily Andini. (2013). http://www.kompasiana.com/penapsikologi/maraknya-fenomena-lesbian-dan-gaydiindonesia_552fd44f6ea83400468b456c 24 Desember 2013

Margaretha. (2014, 17 Desember). Menjaga anak-anak kita dari pelecehan seksual. http://psikologiforensik.com/2014/12/17/menjaga-anak-anak-kita-dari-pelecehan-seksual/. McAnulty, R. D. (2006).

Meilanny Budiarti Santoso, 2016. LGBT dalam Perspektif Hak Asasi Manusia. Social Work Jurnal Volume 62016 Nomor 2 halaman 154-272. https://doi.org/10.24198/ share.v6i2.13206

Mira Fajri. (2016). LGBT dalam Perspektif hukum di Indonesia. (dalam http://www.republika.co.id/berita/ jurnalisme-warga/wacana/16/02/29)

Prayitno. (2017). Konseling Profesional yang Berhasil. Jakarta: Rajawali Pers.

Ronken, C. \& Johnston, H. (2012). Child sexual assault: Facts and statistics. Queensland: Bravehearts

Samuel T. Gladding. (2012). Konseling Profesi yang menyeluruh. Jakarta: Indeks

Suwarsih Madya. (1994). Panduan Penelitian Tindakan. Yogyakarta: Lemlit IKIP Yogyakarta. 